Fatih Irmak, Selami Serhat Şirvan, (1) Merdan Serin*, (1) Kamuran Zeynep Sevim, (1) Ayşin Karasoy Yeşilada, Sevgi Kurt Yazar*

İstanbul Şişli Hamidiye Etfal Training and Research Hospital, Clinic of Plastic, Reconstructive and Aesthetic Surgery, İstanbul, Turkey

*istanbul Training and Research Hospital, Clinic of Plastic, Reconstructive and Aesthetic Surgery, İstanbul, Turkey

Correspondence/ Yazışma Adresi:

Fatih Irmak, İstanbul Şişli Hamidiye Etfal Training and Research Hospital, Clinic of Plastic, Reconstructive and Aesthetic Surgery, İstanbul, Turkey E-mail:dr.fatihirmak@gmail.com ORCID-ID:

orcid org/0000-0002-5842-8195 Submitted/Geliş Tarihi: 04.09.2018 Accepted/Kabul Tarihi: 27.09.2018

${ }^{\circ}$ Copyright 2019 by Turkish Society of Dermatology

\section{Squamous Cell Carcinoma of the Hand: Clinical Presentation, Surgical Treatment, Outcome and Survival Rate: a Series of 129 Cases}

\author{
El Skuamöz Hücreli Karsinomu: Klinik Özellikler, \\ Cerrahi Tedavi Sonuçları ve Sağkalım: 129 \\ Hastalık Serinin Sonuçları
}

\section{Abstract}

Objective: Despite its relative high frequency; the recurrence, metastasis and long-term survival rates of hand squamous cell carcinoma have not been well defined. The aim of this study was to review a large cohort of patients with hand squamous cell carcinomas and to evaluate the management techniques, outcomes of treatment modalities and survival rates.

Methods: A retrospective review of all surgically excised primary squamous cell carcinoma of the hand operated between 2006 and 2011 was included in this multicenter study. Patients were evaluated regarding age, anatomic location of the tumor, gender, treatment modality, survival, and recurrence rate. In addition, recurrence and survival rates were also categorized according to the tumor size.

Results: A total of 129 patients were evaluated. Tumors smaller than $2 \mathrm{~cm}$ had a recurrence rate of $9.7 \%$ and a metastatic rate of $6.5 \%$; tumors larger than $2 \mathrm{~cm}$ had a recurrence rate of $16.7 \%$ and a metastatic rate of $33 \%$ during 5 -year follow-ups.

Conclusion: In contrast to squamous cell carcinoma of the face, those occurring on the hand are malignancies with a worse clinical course, greater tendency for recurrence, metastatic spread, and functional deficiency which might require amputation and complex soft tissue reconstruction.

Keywords: Hand tumors, sentinel lymph node biopsy, squamous cell carcinoma

\section{Öz}

Amaç: Klinik pratikte sık görülmesine ragmen elde görülen skuamöz hücreli karsinomların rekürrens, metastaz ve uzun süreli sağkalımı oranları iyi tanımlanmamıştır. Bu çalışmada geniş bir hasta grubunda elde görülen skuamöz hücreli karsinomlarının tedavi yöntemleri ve sağ kalım oranları değerlendirilmiştir.

Yöntemler: Çok merkezli olan çalışmamızda 2006 ve 2011 yılları arasında opere edilen hastalar çalışmaya dahil edilmiş̧ir. Hastalar yaş, anatomik yerleşim, cinsiyet, tedavi yöntemi, sağkalım ve rekürrens oranına göre değerlendirilmiştir. Ek olarak rekürrens ve sağkalım oranlarının tümör çapı ile olan ilişkisi değerlendirilmiştir.

Bulgular: Yüz yirmi dokuz hasta çalışmaya dahil edilmiştir. Tümör çapı 2 cm'in altında olan hastalarda 5 yıllık takip süresinde rekürrens oranı \%9,7 ve metastaz oran \%6,5 olarak bulunmuştur. Tümör çapı $2 \mathrm{~cm}$ 'in üstünde olan hastalarda 5 yıllık takip süresinde rekürrens oranı \% 16,7 ve metastaz oran \%33 olarak bulunmuştur.

Sonuç: Elde görülen skuamöz hücreli karsinomlar, yüz bölgesine göre daha kötü klinik seyir ile karakterizedir. Rekürrens eğiliminin, metastatik yaylım ve fonksiyonel defisit riskinin amputasyon ve kompleks rekonstrüksiyon gerekebilmesi nedeniyle fazla olduğu görülmektedir.

Anahtar kelimeler: El tümörleri, sentinel lenf nodu biyopsisi, skuamöz hücreli karsinom 


\section{Introduction}

Squamous cell carcinoma (SCC) is the most common skin malignancy of the hand, and eleven percent of all SCCS are located on the hand (1). SCC of the hand is a poorly documented malignancy. Despite its relatively high prevalence, few recent publications are available in the literature, and the majority of these publications are retrospective and include small patient series. SCC is the second most common skin cancer, but its incidence is rising in the recent years, probably due to increased exposure to ultraviolet or sunlight and increased outdoor activities. SCC is an invasive malignant neoplasm of epidermal keratinocytes with squamous phenotypic differentiation. Several risk factors have been defined for SCC, which include Fitzpatrick skin types I and II (usually white individuals), advanced age, ionizing radiation, fair skin, chronic inflammation (e.g., in unstable burn scars), infection with human papillomavirus types 16-18, exposure to chemicals (eg, arsenicals), and certain disease conditions (eg, xeroderma pigmentosa, Bowen's disease).

Anatomical site, size, immune deficiency, carcinomas arising from chronic inflammation (unstable burn scarsMarjolin's ulcer), histologic differentiation of tumor, tumor thickness, the rate of growth and depth determine the incidence of local recurrence and metastasis. Tumors greater than $2 \mathrm{~cm}$ in diameter are twice as likely to recur locally $(15.2 \%$ vs. $7.4 \%)$, and three times as likely to metastasize ( $30.3 \%$ vs. $9.1 \%$ ) compared to smaller tumors (2). The incidence, variety, prognosis, diagnosis and treatment properties of the hand tumors are distinctly different when compared to the other tumors of the body. The tumors affecting the hands account for 10 to $15 \%$ of all skin and soft tissue malignancies (3). The tumors of the hand are usually benign in nature. The indications for surgical removal of hand tumor include functional deficits, cosmetic deformities and to rule out the possibility of a malignancy. The signs of malignancy include rapid changes in size, shape or color, pain and the disability of the hand. However, since its incidence is rare, tumor diagnosis and treatment principles must be well known and should be carefully applied.

For a definitive diagnosis of cutaneous SCC and detection of lymph node metastasis, experienced radiologists and pathologists must be a member of the treatment team. Therefore, the physician has two goals while managing these tumors; the excision of the tumor with a safe margin and aesthetic and functional reconstruction of excised region.

The skin of the hand is a special, mobile structure with a relatively low content of subcutaneous fatty tissue and it covers the important functional structures of the hand. Its reconstruction is also special regarding preserving this functional structure. The aims of this study was to review a large cohort of patients with hand SCCs, to evaluate the management techniques, outcomes of treatment modalities and survival rates according to the primary tumor size.

\section{Methods}

We conducted a retrospective review of all surgically excised SCCs of the hand patients who were operated at our center and İstanbul Training and Research Hospital, Clinic of Plastic, Reconstructive and Aesthetic Surgery over a 5-year period (2006 to 2011). The principles of the 1975 Declaration of Helsinki were followed in this study, and informed consents for the use of their data were obtained from all the patients. The patients were classified according to their age, gender, anatomic localization of the tumor, tumor histopathology, treatment modality, survival and recurrence rate for SCCs. Only pathologically proven SCCs, localized distal to the distal wrist crease were included in this study. Other tumors (malignant melanoma, basal cell carcinomas, soft tissue sarcomas, fibrohistiocytic malignant tumors, bone tumors) and SCCs localized proximal to the distal wrist crease were excluded from the study.

All cases were hospitalized and treated with appropriate respect. Patient files were evaluated for treatment details and recurrence, metastasis and survival rates. All lesions were surgically excised, and for the patients in which sentinel lymph node dissection or elective lymph node dissection was indicated, the dissections were performed simultaneously. All excised materials were investigated by the pathology department for the verification of the diagnosis. The followup data were acquired via control visits, telephone calls and through the medical records of the oncology and the pathology clinics.

The recurrences occurring in the first three months were not classified as a recurrence but were classified as an incomplete excision. While analyzing surgical excision margin data, we referred to the current guidelines of the British Association of Dermatologists for the management of SCC (4).

\section{Statistical Analysis}

Statistical analysis was performed using Prism 7 Software (GraphPad Prism version 7.00 for Mac, GraphPad Software, La Jolla California USA). For comparison among different groups, the Mann-Whitney $U$ test (unpaired, non-parametric) was used. A p value less than 0.05 was considered significant.

\section{Results}

Over the 5-year period, 129 patients were evaluated concerning their age, gender, anatomic localization of the tumor, treatment modality, survival and recurrence rate (Tables 1, 2, 3). The mean follow-up period was 62 months (38118 months). SCC was accounted for $65.2 \%$ of all malignant lesions of the hand. SCC of the hand was more frequently seen in men $(n=74)$ than in women $(n=55)$. The mean age of presentation was 63 years (37-81 years) in men and 60.3 years ( $45-92$ years) in women (Table 1 ). $44.3 \%$ of the patients $(n=57)$ had a history of skin cancer. $33 \%$ of the cases $(n=43)$ presented in this study had poorly or un-differentiated tumor type with $18 \%$ recurrence rate while $66 \%$ of the cases $(n=86)$ presented in this study had a well/moderate differentiation 
with $8.2 \%$ recurrence rate. The lesions of the $36.4 \%(n=47)$ of the patients were localized on the dorsum of the hand while those of $48.1 \%$ ( $n=62)$ were localized on the dorsum of the fingers and metacarpophalangeal joint. The lesions of $8.5 \%(n=11)$ of the cases were localized around the nail bed, those of $7 \%(n=9)$ were localized in the interdigital area. A statistically significant difference was observed regarding metastasis and local recurrence rates in the web spaces and dorsum of finger-metacarpophalangeal (MCP) joint compared to the other regions $(p<0.005)$ (Table 2$)$.

The treatment modalities did vary according to the tumor type and its invasive characteristics (Table 3). The treatment was excision or simple amputation in 48 of the cases, excision and local flap in 9 cases and excision and skin grafting in 42 cases (Figure 1). Ray amputation was performed in 15 cases and tumor excision with tissue defect reconstruction using a distant flap (pedicled flaps -inguinal flap, abdominal flapand free flaps) was performed in 15 patients (Figure 2). In $72 \%(n=93)$ of the cases, the tumor diameters were less than $2 \mathrm{~cm}$. Additionally, in this group, six patients had a palpable

\begin{tabular}{|c|c|}
\hline Mean age, years & $61.8 \pm 0.6$ \\
\hline Female & $60.3 \pm 0.9$ \\
\hline Male & $63 \pm 0.7$ \\
\hline Age range, years & $37-92$ \\
\hline Female & $45-92$ \\
\hline Male & $37-81$ \\
\hline Male: female ratio & $1: 0.75$ \\
\hline Follow-up time (months) & 62 (range $38-118$ ) \\
\hline Previous skin cancer & $44.3 \%$ \\
\hline
\end{tabular}

lymph node. Thus, after determine the pathology result with fine-needle aspiration biopsy, elective lymph node dissection was performed as well. The pathology results showed that metastasis to these lymph nodes was positive in all patients. Lesion smaller than $2 \mathrm{~cm}$ had a recurrence rate of $9.7 \%$, and the metastasis rate during the five year follow-up was $6.5 \%$.

In $28 \%(n=36)$ of the cases, the tumor diameter was larger than $2 \mathrm{~cm}$. Elective lymph node dissection was performed in 16 of 36 patients who had radiologically-pathologically (fine-needle aspiration biopsy) proven and clinically palpable lymph nodes. The pathology results revealed that metastasis was present in the lymph nodes of these 16 patients (Table 4). We performed SLND on the remaining 20 patients who had non-palpable lymph nodes. The pathology results of eight patients demonstrated metastasis in these lymph nodes. Tumors larger than $2 \mathrm{~cm}$ had a recurrence rate of $16.7 \%$ and their metastasis rate during five-year follow-up was $33 \%$. The five-year survival rate of the patients with large tumors was 85\% (Table 4).

\section{Discussion}

SCC makes up approximately $20 \%$ of all skin cancers and nearly $75 \%$ of all malignant skin lesions observed in hand $(5,6)$. In our study, $65.3 \%$ of all malignant cutaneous lesions of the hand were SCCs. Its association with sun exposure predisposes to the development of SCC on the dorsum of the hand. SCC is mostly localized on the dorsum of the hand, dorsum of the fingers, and interdigital area, respectively (1). Its risk factors include fair skin, cumulative over-exposure to ultraviolet radiation, advanced age, and chronically damaged skin. The primary choice of treatment is surgical excision. The risk of metastasis and rate for recurrence for SCC of the hand was reported as greater on the hand dorsum than other locations $(7,8)$. Whereas in the present study, local recurrence,

Table 2. Recurrence and metastasis rates according to anatomical localization

\begin{tabular}{|l|l|l|l|l|}
\hline Localization & $\begin{array}{l}\text { Dorsum of the hand } \\
(\mathbf{n = 4 7 )}\end{array}$ & $\begin{array}{l}\text { Dorsum of the finger and } \\
\text { MCP joint }(\mathbf{n}=\mathbf{6 2})\end{array}$ & $\begin{array}{l}\text { Nail bed } \\
(\mathbf{n}=\mathbf{1 1})\end{array}$ & Web space (n=9) \\
\hline Local recurrence (\%) & 8.9 & 13.6 & 10.6 & 13.9 \\
\hline Metastasis (\%) & 11.3 & 15.9 & 12.9 & 16.3 \\
\hline MCP: Metacarpophalangeal & \multicolumn{3}{l}{} \\
\hline
\end{tabular}

Table 3. Treatment modality for the squamous cell carcinoma of the hand

\begin{tabular}{|l|l|l|l|l|l|}
\hline $\begin{array}{l}\text { Excision (simple } \\
\text { amputation) }\end{array}$ & Excision + graft & $\begin{array}{l}\text { Excision + ray } \\
\text { amputation }\end{array}$ & $\begin{array}{l}\text { Excision + local } \\
\text { flap }\end{array}$ & Excision + distant flap & Total \\
\hline 48 & 42 & 15 & 9 & 15 & 129 \\
\hline
\end{tabular}

Table 4. Recurrence rate, metastasis rate and indication for lymph node dissection in squamous cell carcinoma cases according to tumor diameter

\begin{tabular}{|l|l|l|l|l|l|l|}
\hline & & SLND & ELND & Result of ELND & Recurrence rate & Metastasis rate \\
\hline Less than $2 \mathrm{~cm}$ & $\mathrm{n}=93$ & - & $\mathrm{n}=6$ & $\mathrm{n}=6(+)$ & $9.7 \%$ & $6.5 \%$ \\
\hline Larger than $2 \mathrm{~cm}$ & $\mathrm{n}=36$ & $\mathrm{n}=20[\mathrm{n}=8(+)]$ & $\mathrm{n}=16$ & $\mathrm{n}=24(+)$ & $16.7 \%$ & $33 \%$ \\
\hline
\end{tabular}


as well as metastasis rate, were determined to be higher on other regions of the hand.

It has been shown previously that ninety-five percent of the low-risk lesions can be excised successfully with a minimum
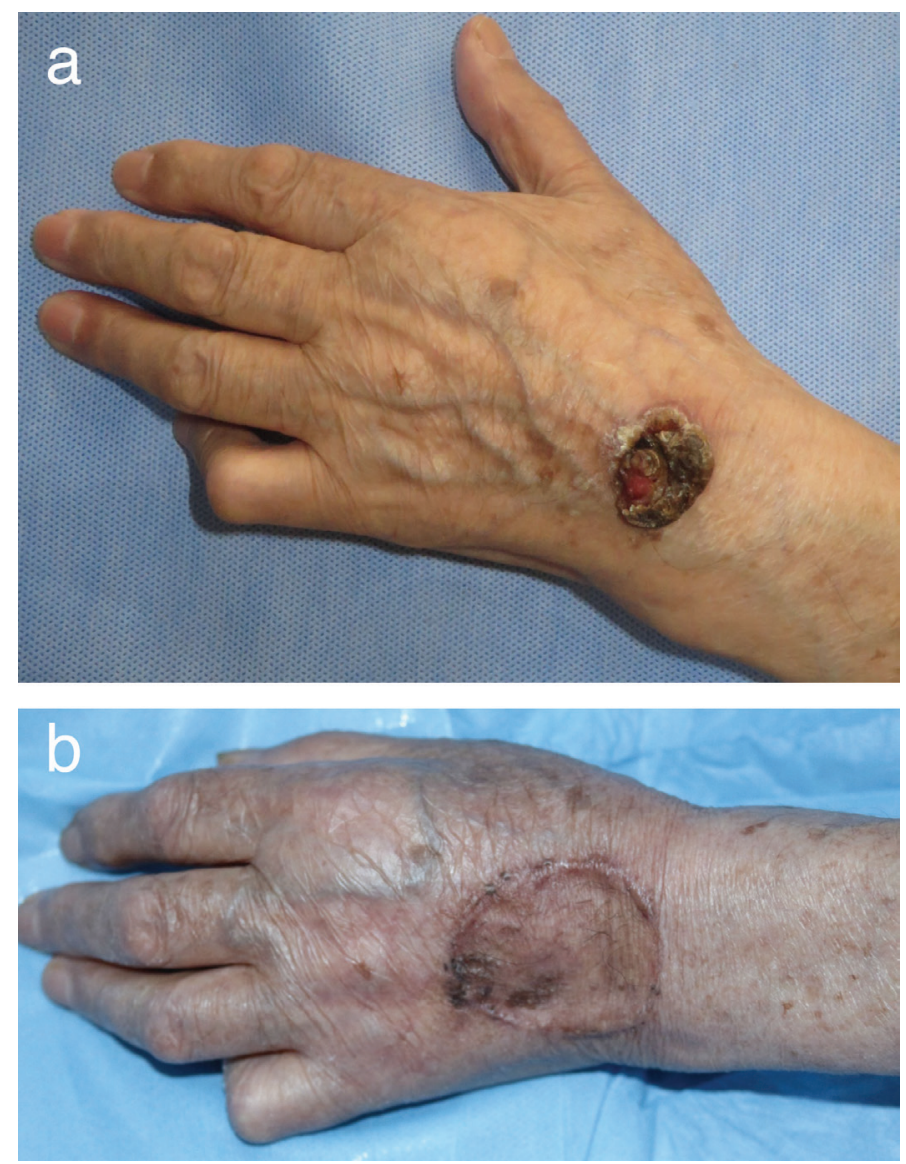

Figure 1. a) Preoperative photograph of a squamous cell carcinoma on the hand dorsum, b) Photographs taken in the postoperative fourth year, after excision and skin grafting

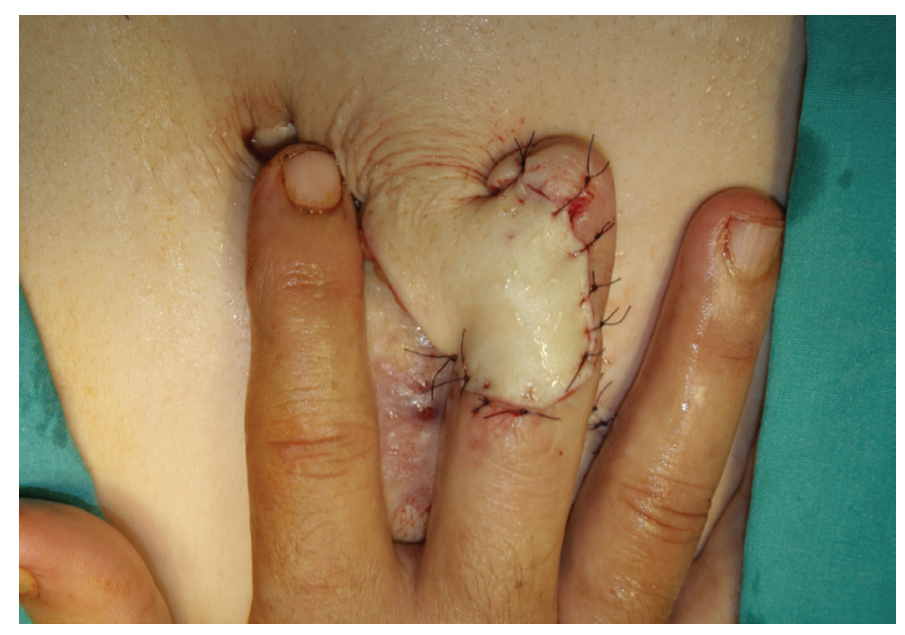

Figure 2. Postoperative photograph of a third finger squamous cell carcinoma after excision and reconstruction with a pedicled abdominal flap of $4 \mathrm{~mm}$ margin while high-risk lesions required minimum of $6 \mathrm{~mm}$ margins for adequate resection (4). Distal amputation is required if the tumor invades the bone. After excision, defect closure can be performed by simple amputation, local tissue rearrangement or local flaps, skin grafts and distant flaps. Current evidence does not recommend the routine use of sentinel lymph node biopsy for low-risk lesions because the results have shown a low rate of lymph node metastasis (9). Maruyama et al. (10) noted that they did not perform sentinel lymph node biopsy (SLNB) for their patients with T1 tumors.

But according to our study, 6 of 93 patients with tumor smaller than $2 \mathrm{~cm}$, had radiologically-pathologically proven and clinically palpable lymph nodes, thus an elective lymph node dissection was performed in these six patients. In all of these patients pathological examination revealed lymph node metastasis. Alternatively, high-risk lesions may benefit from sentinel lymph node biopsy for the diagnosis of subclinical lymph node metastasis (9). In a previous study, lesions smaller than $2 \mathrm{~cm}$ had a local recurrence rate of $7.4 \%$ and a metastasis rate of $9.1 \%$ while tumors larger than $2 \mathrm{~cm}$ in diameter had a local recurrence rate of $15.2 \%$ and a metastasis rate of $30.3 \%$ (11). According to our study similar rates were found with the tumors larger than $2 \mathrm{~cm}$. The tumors with less than 2 $\mathrm{cm}$ in diameter had higher local recurrence rate and lower metastasis rate when compared with this previous study (Table 4). If there is no clinically or radiologically positive lymph nodes, small lesions (less than $2 \mathrm{~cm}$ ) do not require lymph node dissection.

In our study, poor prognostic factors for the hand SCCs were tumors which were larger than $2 \mathrm{~cm}$ and the ones localized in the web spaces and dorsum of fingers and MCP joints. These factors cause a statistically significant increase in recurrence and metastasis rates. $(p<0.005)$ (Table 2,4$)$. In previous studies, the localization especially in the web spaces and dorsum of proximal phalanx were emphasized to be poor prognostic factors $(12,13)$. In addition, the dorsum of mid-phalanx and MCP joint were also identified as a poor prognostic factor. Maciburko et al. (12) suggested that the reason for a higher lymph node metastasis in the high-risk regions might have been attributed to the fact that a more conservative approach is adopted in the excision of the tumor in these regions and that the intense nature of a lymphatic system which is present in this region.

Elective lymph node dissection was performed in radiologically-pathologically proven and clinically palpable lymph nodes in 16 of 36 patients with tumors larger than $2 \mathrm{~cm}$. The pathology results showed that lymph nodes metastasis was present in all of these patients (Table 4). We performed SLNB in non-palpable lymph nodes in the remaining 20 patients. The pathology results of eight patients revealed metastasis in these lymph nodes. However, it should be noted that SLNB is not free from complications. Wound complications (e.g., seroma, hematoma, or infection) and sensorial morbidity which occurs mostly in the axilla (e.g., 
pain, mobility limitation, or discomfort) have been reported. We have not encountered any complications due to SLNB in our series.

The recurrence rate for SCC is determined by its differentiation degree. Poorly-differentiated or undifferentiated SCCS have been reported to have $28 \%$ recurrence rate while well differentiated SCCs have 7\% recurrence rate (13). According to our study poorly or undifferentiated $43 \mathrm{SCC}$ cases had $18 \%$ recurrence rate and well-moderately differentiated 86 SCC cases had $8.2 \%$ recurrence rate. According to our study, in 7 patients, SCC arose in the area of traumatic scarring, and in 4 patients SCC arose from actinic keratosis. But we cannot confirm the absence of pre-existing lesions in the remaining patients since these lesions are usually not reported or consulted until they undergone a malignant transformation. In conclusion, according to our study, it was not possible to confirm an association between pre-existing lesions with the SCC of the hand.

Adequate tumor control is the most critical entity in hand SCCs. Amputation may be necessary when clear margins cannot be obtained by other surgical approaches. In situations where the pathological result is uncertain, or the frozen section is unreliable, additional tissue must be sent for pathological analysis and definitive reconstruction should be delayed (14). Over the past five years, we have analyzed 129 SCCs of the hand.

\section{Study Limitations}

There are some limitations of this study which arise from the fact that it is a retrospective study. Also, there is lack of a control group, which hinders more robust comparison of results. The results should be interpreted in the light of these limitations.

\section{Conclusion}

In contrast to SCC of the face, those occurring on the hand are malignancies with a worse course, greater tendency for recurrence, metastatic spread, functional deficiency, and the need for amputation and complex soft tissue reconstruction. Early detection and intervention are essential for prognosis and survival in all of the malignant hand tumors. The surgeon's primary goal should be the excision of the tumor with a safe margin while maintaining functionally and aesthetically satisfactory results.

\section{Ethics}

Ethics Committee Approval: Retrospective study.

Informed Consent: Informed consents for the use of their data were obtained from all the patients.

Peer-review: Internally peer-reviewed.

\section{Authorship Contributions}

Concept: F.I., Design: M.S., Data Collection or Processing: F.I., S.S.Ş., Analysis or Interpretation: K.Z.S., A.K.Y., Literature Search: M.S., S.K.Y., Writing: M.S., F.I.

Conflict of Interest: No conflict of interest was declared by the authors.

Financial Disclosure: The authors declared that this study received no financial support.

\section{References}

1. TerKonda SP, Perdikis G. Non-melanotic skin tumors of the upper extremity. Hand Clinics 2004;20:293-301.

2. Clayman GL, Lee JJ, Holsinger FC, et al. Mortality Risk From Squamous Cell Skin Cancer. Journal of Clinical Oncology 2005;23:759-65.

3. Martinez J-C, Otley CC. The Management of Melanoma and Nonmelanoma Skin Cancer: A Review for the Primary Care Physician. Mayo Clinic Proceedings 2001;76:1253-65.

4. Motley R, Kersey P, Lawrence C. Multiprofessional guidelines for the management of the patient with primary cutaneous squamous cell carcinoma. British Journal of Dermatology 2002;146:18-25.

5. Bean DJ, Rees RS, O'Leary JP, et al. Carcinoma of the Hand: A 20-Year Experience. Southern Medical Journal 1984;77:998-1000.

6. Chakrabarti I, Watson JD, Dorrance H. Skin Tumours of the Hand. Journal of Hand Surgery 1993;18:484-6.

7. S. A. Benign and malignant soft tissue tumors of the hand. . In: McCarthy JG MJ, Littler JW editor. Plastic Surgery. Vol 8. Philadelphia:WB Saunders; 1990. p. 5483-509.

8. Schiavon M, Mazzoleni F, Chiarelli A, et al. Squamous cell carcinoma of the hand: Fifty-five case reports. J Hand Surg Am 1988;13:401-4.

9. Henderson MM, Neumeister MW, Bueno RA. Hand Tumors. Plastic and Reconstructive Surgery 2014;133:154e-64e.

10. Maruyama H, Tanaka R, Fujisawa $Y$, et al. Availability of sentinel lymph node biopsy for cutaneous squamous cell carcinoma. J Dermatol 2016;44:431-7.

11. Rowe DE, Carroll RJ, Day CL. Prognostic factors for local recurrence, metastasis, and survival rates in squamous cell carcinoma of the skin, ear, and lip. J Am Acad Dermatol 1992;26:976-90.

12. Maciburko SJ, Townley WA, Hollowood K, et al. Skin cancers of the hand: a series of 541 malignancies. Plast Reconstr Surg 2012;129:1329-36.

13. Rayner CRW. The Results of Treatment of two Hundred and SeventyThree Carcinomas of the Hand. Hand 1981;0s-13:183-6.

14. Labow BI, Greene AK, Upton J, et al. Soft Tissue Sarcomas of the Hand: Functional Reconstruction and Outcome Analysis. HAND 2008;3:229-36. 